\title{
Paradigms of Dominance and Relationships of Exchange in the Andes
}

\author{
Allison Ramay \\ Pontificia Universidad Católica de Chile, Faculty of Letters
}

Received 30 March 2018 • Revised 20 June 2018 • Accepted 10 July 2018

\begin{abstract}
By juxtaposing close readings of four studies on exchange in the $19^{\text {th }}$ and $20^{\text {th }}$ century Andean region, we can better understand how pre-existing perceptions about indigenous groups played into relationships of exchange, as well as how these relationships contributed to form ideas about race, political agency, and economic power.

Keywords: Andes, exchange, commoditization.
\end{abstract}

In $19^{\text {th }}$ century Latin America, independence movements and modernity involved complex forms of negotiation between indigenous populations, local elites, and capitalistic powers abroad. Interactions of trade, gift giving, and commodity exchange from that period have been the focus of published scholarly studies by Michael Taussig, Ariel de la Fuente, and Deborah Poole. Mary Weismantel's work contributes to this group through her study on exchanges in the Andes region in the $2 \mathrm{O}^{\text {th }}$ century. By juxtaposing these four studies, we can better understand pre-existing perceptions about indigenous groups, some of which were passed on from the colonial period, as well as paradigms in formation regarding race, political agency, and economic power.

When studying relationships of commodity exchange there are, as Arjun Appadurai suggests, many perspectives that one can take: we may focus on the object, the value of the object within a given reality, the traders, and/or the relationship between both. Particularly interesting in the negotiations in the aforementioned texts is that while commodities act as avenues through which groups maintain or gain control over others, trade also complicates binary relationships of subject/object, dominant/dominated, etc. Considering this paradox, we may question why certain cases of trade involve great physical violence, when others do not. What role do paradigms of historical dominance play in how these relationships of exchange occur? In this paper I will examine how the four authors approach instances of commodity exchange in the Andes, and analyze how each, directly or indirectly, comments on pre-existing paradigms as well as the formation of paradigms about Indians through relationships of exchange and the different notions of violence involved in each.

Relationships of trade or exchange are not formed outside of historical relationships and often reflect pre-existing notions about the relationship between the participants of the exchange. At the same time, the objects traded are usually related to the immediate needs or "desires" of the participants. As Appadurai states, we know that objects alone do not have value but rather, demand for them endows them with value. Likewise, the value of objects changes and

(C) Authors. Terms and conditions of Creative Commons Attribution 4.0 International (CC BY 4.0) apply. Correspondence: Allison Ramay, e-mail: aramaya@uc.cl. 
as a result, they move in and out of the commodity state. In other words, commoditization of objects is a process that changes during a given historical moment and people may manipulate the commodities deemed "valuable" in order to come closer to their own personal objectives. For this reason, not only objects of trade but also, the reasons for which objects are traded tell us a great deal about the interests of those involved in the exchange, as well as their respective perceptions of those with whom they trade.

- Relationships of trade or exchange are not formed outside of historical relationships and often reflect pre-existing notions about the relationship between the participants of the exchange.

- Bringing these text into dialogue allows us to conceive physical and symbolic violence as equivalents, as well as to better appreciate figures who resist that very violence, in the figure, for example, of the chola.

The first text we will consider, Shamanism, colonialism, and the wild man, written by Michael Taussig (1987), documents the political and economic backstage of the Colombian rubber boom of the early 1900s. As local elites and British company managers exploited the rubber on a macro-level they required a substantial workforce. While they had to compete with private individuals or traders who made a living off of the rubber, the Arana brothers, owners of a large company owned in part by Peruvian and British capitalists, had a successful system for obtaining Indian labor: forcing them to submit to a form of exchange known as "debt-peonage". Taussig's documentation comes out of the trial and investigation held by the British House of Commons Select Committee on the Putumayo that took place following the disarray of locals who witnessed the enslavement, torture, and murder of Indians that had been forced into relations of debtpeonage. Most of his citations come from the testimonies and diaries of Roger Casement who was sent by the British government to the Putumayo region as a consular representative in order to investigate the grievances, Walter Hardenburg, a North American who was captured by Arana's men, and Joaquin Rocha, a Colombian who knew the Putumayo region from his travels in 1903. Taussig uses the accounts of these men to expose the different versions of how and why Indian groups were treated so brutally, with the common end being forced labor for extraction of rubber. Taussig is fascinated by the senselessness involved in "the fiction of trade", however the details of how the trade actually occurred are somewhat ambiguous. As we will see, one of Taussig's explanations for this brutal violence is the notion of commodity fetishism.

In Casement's testimony he states that giving Indians valuable objects and indebting them was a pre-text for obtaining them for labor and this process occurred under the guise of "giftgiving", "advances", and "trade". From Taussig's research and analysis, we find that this form of indebting was inconsistent, and constructed for the sole purpose of enslaving Indians. As Casement states in the Putumayo Report, "When the Indians agreed to work rubber, after being caught, they would get things given to them, i.e., cloth etc., a shirt, a pair of pantaloons, a cutlass, axe, powder and shot, and perhaps trade guns"' (Taussig, 1987: 65), after which time, they would be expected to continue extracting rubber. Indians were "caught" in correrías (which Taussig describes as slave raids) and by conquistas, a term that was highly problematic and unclear for the Committee but which Arana described as "to attract a person to conquer their sympathies" (Ibid., 28). Is it possible then, that in order to "catch" Indians they would offer them material goods? If so, then the objects given to Indians could have been interpreted as "gifts" in the sense that upon receiving them, they might not have been aware of the labor obligation that was involved. Joaquin Rocha documented an earlier system of exchange (between the Tama and Coreguaje Indians and their patrons) in which certain items were considered "gifts" (rum and tobacco) and others were given only as advances for rubber (cloth, guns, axes, etc.) (Ibid., 28). In this way, while the investigation of the Committee reveals that gifts or advances served to entangle Indians into relationships of debt, in different regions the process for indebting Indians differed, as most likely did their own concepts of trade. Although possibly outside of the scope of Taussig's study, it would 
be informative to have insight on the Putumayo Indians' understanding and modes of trade, as this would help explain why they accepted or declined initial offers by capitalists to engage in relationships of exchange ${ }^{1}$.

Through the testimonies of the Trial, we also learn that Casement and Hardenburg had different ideas about the motivations for such extreme violence against the Putumayo Indians. Casement believed that the men of Arana's company were fighting for a scarce resource of labor while Hardenburg believed that it was "senseless brutality". Throughout the first part of the book, we learn that many of Arana's workers believed that labor was indeed scarce, yet this belief did not stop them from ritualistic and morbid mass killings of Indians. Taussig suggests that Casement and those who shared this opinion was based less on truth than on fears that existed from the colonial period regarding cannibalism and the threat of Indian rebellion. Therefore, according to Taussig, in the minds of the capitalist "conquistadores", their only option was to inculcate fear in order to coerce Indians to work for the company.

As we have seen, Taussig understands both the violence against the Putumayo Indians as well the reaction of the Indians as intimately linked to traumas suffered during the colonial period. For the author, the debt-peonage system is a repetition of the original trauma of colonization in the XVI century. In the "space of death", a state of being expressed by the Putumayo Indians, Taussig suggests that it involves the imaginaries of both Europeans and indigenous peoples that are continually dealing with the trauma of colonization. "With European conquest and colonization, these spaces of death blend into a common pool of key signifiers binding the transforming culture of the conqueror with that of the conquered" (Taussig, 1987: 5). Taussig notes that for Indians of the Putumayo, the space of death means to no longer be alive while living. It implies a loss of personhood and creates the sense that one has become a wandering, placeless object. Taussig first learned about the space of death from an Ingano Indian who suffered from fever.

With the fever I was aware of everything. But after eight days I became unconscious. [...] Of the pain of the fever, I remembered nothing; only the space of death. [...] Of the world I knew nothing, nor the sound of my ears. [...] I was searching, to find me a place in the five continents of the world (Taussig, 1987: 7).

Though a single account of this space, the author sees in these words a human that has been transformed into a "thing"; an object. Taussig's analysis of the effects of debt-peonage in the imaginaries of Indians in relationship to the actions of Arana's workers reveals his belief that local elites and company managers began to "see" the Indians as human debts. As axes, cloth, and other items were exchanged to entangle the debtors, Indians too were treated and seen as commodities, and in this way, they were the objects of Marx's commodity fetishism². As Taussig states, "And if one asks, what is a debt? In a situation in which goods called advances or gifts are forced onto unwilling recipients, the answer is a man, or failing that, an Indian or a peon" (Taussig, 1987: 70).

\footnotetext{
${ }^{1}$ The author cites Hardenburg saying, "Indians received their advances with great pleasure, because if they did not, they were flogged to death" (72). But Taussig also refers to Indians in the northern area of Arana's territory that denied advances. Considering that exchanges changed over time as Indians in the region found out about the false trade, it would be interesting to know how initial exchanges occurred.

2 According to an online encyclopedic definition, commodity fetishism is "the inauthentic state of social relations, said to arise in complex capitalist market systems, where people mistake social relationships for things." (http://www.nationmaster.com/encyclopedia/Commodity-fetishism.) Within Taussig's text he states that commodity fetishism is one of the main explanations for the "conqueror's" treatment of the Indians as human "debts". "This cost-accounting way of building sense presupposed and hence reinforced as eternal verities the notions of market pressure, the capital-logic of commodities, and the rationality of business. Thus even in blaming the market, its mode of appropriating reality and creating intelligibly was upheld" (53).
} 
While it is clear that debt-peonage was a system of slavery and the Indians were considered commodities, it is not clear as to why such violence was continually used. Were the managers so sure that extreme violence was the only way to keep the Indians under their control? Is it possible that the rubber industry itself was unstable and therefore committing atrocious acts against defenseless Indians was a form of self-vindication? Taussig does not answer these questions specifically but they will serve as interrogatives for the next texts we examine in which little or no physical violence is involved.

In Ariel de la Fuente's Children of Facundo (2000), he examines patron-client relationship between gauchos and caudillos in the Argentinean provinces in the second half of the XIX century. In stark contrast to Taussig's account, the participants of these patron-client relationships identify with each other due to common geography, basic needs, and in some cases, political goals. Their relationships are based, therefore, not only on commodity exchange, but also on an emotional and moral "debt" linked to the material support and political protection provided by the caudillo in their particular regions. When considering the gaucho and the caudillo as historical figures, it is important to mention that fictional and literary representations as well as common descriptions of gauchos tend to emphasize their roles as criminals and bandits 3 . De la Fuente, however, examines the complexities of the relationships of exchange between gauchos and caudillos, which led to political agency and informed individual and national identities.

When we compare gaucho-caudillo alliances to the enslavement of the Putumayo Indians, we find that these patron-client relationships of Argentina are based on consistent and shared beliefs about the relationship. In terms of material commodities, it is noteworthy that the gauchos that participated in the montoneras trusted that they would be compensated, as was "custom". As de la Fuente explains, during the mobilization of montoneras, they would eat beef (from cattle rustling), they would receive clothes and shoes, and in some cases they would receive cash (from looting). The gauchos who were willing to do this work would receive the material goods and, in some cases, salaries and promotions.

The caudillo, on the other hand, had an obligation to provide protection, material and political, for his gauchos. "Assistance [...] was not only a moral obligation for the caudillo; he was also aware that it permanently tested the patron-client relationship" (de la Fuente, 2000: 101). This relationship involved stepping in to protect gauchos if they were in legal binds, and being generous when gauchos needed financial support. Part of the caudillo's ability to offer this kind of protection was based on their reputations that became, as de la Fuente says, an "acquired right that gauchos learned to use and manipulate" (Ibid., 102). In one case, a laborer was arrested by a merchant in La Rioja and, having participated in two Federalist montoneras he exclaimed that "the chief of police would pay for the damage their accusations had done to him when General Peñaloza arrived" (Ibid., 103), when in fact Chacho was in a different province at that time. This threat was enough for the suspension of the accusation (at least until after the assassination of Chacho). As we can see then, caudillos had to be reliable patrons in order to build a patron-client relationship of trust, and at the same time gauchos could potentially use the reputations of the caudillos to obtain liberties.

\footnotetext{
3 As de la Fuente explains, the meaning of the term "gaucho" depended on the speaker. It tended to include different ethnic categories and could be used to mean "all those who live in the countryside" (75). The meaning the author refers to is "poor inhabitants of the countryside" (76). He makes the distinction that for neighbors within rural areas the word meant, "those involved in cattle rustling or any other type of crime, even assassination," (76) and similarly, in the 1860s "provincial authorities and national government officials also used gaucho as a synonym for bandit" (77). Many times this particular use was the result of Unitarian agendas. The most well known account in canonical literature regarding the gauchos after Independence are a book of published essays written by Domingo F. Sarmiento entitled Facundo (1845) in which he argues that the gauchos must be exterminated as they inhibit progress of the nation.
} 
In addition to the material support that caudillos provided, De la Fuente reveals that in oral tradition, caudillos are described as having Christ-like characteristics: not only are they omniscient and omnipresent, in some stories caudillos would repay the gauchos because of their loyalty in unusual circumstances. In one story, a peon who unknowingly helps Quiroga cross a river is later rewarded with ten oxen and ten cows. The significance of this story is understood in the poverty of landless Argentines. "(The compensation) allowed the peon to begin raising cattle, thereby distancing him from the periodic specter of hunger that was part and parcel of casual wage labor and subsistence agriculture" (de la Fuente, 2000: 128). When we consider this aspect of rural Argentinean reality and lacking resources and commodities, which the caudillos could provide, we see that these leaders merited stories about their Christ-like attributes.

The patron-client relationships of the Argentinean provinces revolved heavily around material exchange as well as the emotional and psychological security provided by that exchange. When we consider the political weight of the gaucho-caudillo collaboration under the Federalist banner 4 in opposition to the Unitarians, it seems that the sheer number of "loyal" gauchos facilitated political strength. At times the Unitarians wished to capitalize on the "masses", as the gauchos were derogatorily known, in order to move towards their goal of central government yet they were rarely successful5. In this equation, if one group were to use excessive and massive violence, comparable to that of the Putumayo region, against another it seems that it would have been the Unitarians against the gauchos. Because of the debts and exchanges that were mostly faithful, incurred by the gauchos with their patrons, as a unit their collaboration was difficult to penetrate or threaten at this time. Their bond and strength as a group, then, was partly enabled by consistent exchanges of commodities that enabled forms of agency for both parties.

We can also understand the loyalty involved in the patron-client bond when we consider that a central government was in formation in Argentina but that the gauchos and caudillos had control in the provinces. Though a very Mary Roldan explains that La Violencia of 1946-1953 in Colombia, resulted from unstable or unreliable relationships between the people, the municipal and departmental authorities, and the central government. When the "peoples" needs were not met by their respective elected officials, some took the matter into their own hands through violence against the State. According to one of her sources, parties guaranteed to satisfy peoples' basic needs and if a group's respective party was not elected, "Cualquier conflicto entre los partidos inevitablemente conducía a un conflicto generalizado"( de la Fuente, 2000: 44). In terms of the gaucho-caudillo collaboration, this relationship provided the gauchos with many necessities and politics were dealt with on a micro-level, by way of the caudillo.

Our next example is a text written by Deborah Poole (1997) entitled Vision, race, and modernity: A visual economy of the Andean image world. As in the previous two texts, Poole deals with exchange between indigenous communities and local elites, as well as European consumers. Whereas in the other texts, patron-exchange took place via material commodities between individuals, by contrast this text presents an exchange in which Indian bodies constitute commodities. The original carte-de-visite was a small photograph that individuals traded or gifted to friends and acquaintances in 19th century Europe. The photographers of the carte-de-visite would emphasize, through lighting and poses, the traits deemed most valuable or esteemed among the bourgeoisie class. Poole notes that in reality, the carte-de-visite represented a global class as

\footnotetext{
${ }^{4}$ According to the author, most gauchos considered themselves to be Federalists although after the death of the most famous caudillos such as Chacho, gauchos were wary of political leaders from either party. He also mentions that for Chachistas Federalism was deeply rooted in gaucho culture and identity (106).

5 An exemplary case is of the Dávila family who suffered from their inability to gain the support of the gauchos under the Unitarian cause. After several member were killed, "A Unitarian from La Rioja, showing disgust with the Dávilas' new political line, commented at the time that the family, "now calls itself Federalist, believing that it will thus attract the masses" (110).
} 
cartes from different European countries were strikingly similar. With the invention of the stereoscope, which produced a three-dimensional image, the carte-de-visite of the bourgeoisie class became less popular yet they were considered the perfect medium for categorizing "types."

Throughout the $19^{\text {th }}$ century, an interest in categorizing racial phenotypes in the Andes region, led scientists to use the carte-de-visite for that very purpose. The new "colonial" or "type" carte-de-visite displayed different Andean Indians categorized by their trade: water carrier, Indian brigade, landowner, peon, as well as by racial type. Interestingly, the carte-de-visite "culture" did not change as these continued to be displayed, collected, and traded. But one of the largest differences was that, while the original carte-de-visite was collected as proof of a person's "moral achievement" such that the cartes were representative of the quality and breadth of one's social circle, type cartes were desirable for their aesthetic quality. Their value as Poole states, differed from the carte-de-visite in that they were, "emptied of what we might think of as the "photographic use value' of representing reality" (Poole, 1997: 141). While the photographs of the colonial cartes could not be linked to any specific reality for the non-traveling bourgeoisie, they had a capacity to contain the "exotic" images. Poole argues that their popularity, as Baudrillard's states, was based on "the passion for the code... the ambivalent fascination for a form [that is the] logic of the commodity or system of exchange" (Ibid., 141).

When we consider the role that the Indians had in the process of creating the cartes, Poole shows that Andean Indians were maintained at a distance that was considered "safe". The cartes served to bring those from the altiplano who, as Poole points out, had not technically been "colonized", into a realm that was familiar to European bourgeoisie of the "colonial other". Similarly, prominent Andean figures such as the gaucho who were associated with Argentinean nationalism as we saw in de la Fuente's text, were rendered yet another "type" of Indian within the broad category of "American Types". The small photographs functioned to reassure the bourgeoisie that these Indians were void of history and subjectivity. The photographs were aesthetically pleasing and it is important to note that the images reinforced beliefs that were already very much a part of European and Indian imaginaries: The poses were often false yet Indian models would "perform" in exchange for small gifts and in some cases without any compensation. In this way we may see that the imaginaries that took part in the production and consumption of the photographs were very similar to the ones that participated in the violence of the Putumayo Indians. Though the photographs caused no physical deaths, as subjects, the Indians in both cases were contained in the dominant discourse through their exclusion as subjects.

In the mid 1800 shen migration to major cities increased throughout Latin America and urban and marginalized spaces were defined by Modernity, these photographs renewed a practice that was common in the colonial period of Latin America: categorizing mixed races, or castes, which were considered a threat to the established order. In the 18th century caste paintings were meant to reinforce the hierarchies between races at a time when racial mixing was cause for concern among the ruling Spanish and criollo elite. In the $19^{\text {th }}$ century, these cartes were similarly meant to capture and enclose the unfamiliar Andean highland Indians that, though physically distant, could be capitalized on through commodity fetishism. As we have seen, figures within the same time period such as the gaucho who continually posed a threat to Unitarian leaders and had a system of organization that was difficult to penetrate, could be tucked away in the category of "American Type". In Poole's work, we find that while physical distance separated the Europeans from the Andean Indians, the cartes created a reassurance of difference through commodity fetishism. As we saw in Taussig's account of the Putumayo Indians, "differences" between Europeans, local elites, and Indian communities can be maintained through violence as well as through commodity fetishism. Poole is careful, though, not to essentialize Europeans as having a 'predisposition to misrepresent or belittle the 'other"' (Poole, 1997: 27), and emphasizes the role of growing capitalism within a global culture to explain their popularity as commodities. As she 
links the production of the cartes to the anatomical equivalences created by French physical anthropologist Arthur Chervin, and the criminal typologies of Alphonse Bertillon, we see that their common denominator is that they established difference. In light of this connection, it is interesting to question the role of fear, stemming from Modernity with echoes from colonial fears, in the production of these pictures. As we have seen, the Indians became the material commodity whose difference was controlled and contained by the photograph.

A counter-example to this control over difference is found in one of the albums used by Poole from Dr. L. C. Thibbon, a Bolivian consul in Brussels, which epitomizes the organization and "sameness" afforded by the colonial cartes, and gives insight into the European fascination with the figure of the Bolivian chola. The chola forms part of Mary Weismantel's (2001) study in Cholas and Pishtacos: Stories of race and sex in the Andes and as Poole stated, she represents a space outside of racial categories, as she is not considered mestiza, Indian, or white. The chola is a woman who draws attention because she defies and challenges norms associated with her gender and racial identity: She is a loud and confident woman, in charge of a business, and she is not of the "dominant" race. What is particularly interesting about the chola in relationship to the other "traders" we have examined is that her image, like that of the caudillo, is intertwined with her job. Therefore, while her vendor skills are indeed important, so too is the fact that she instills unease in others because she cannot be categorized.

In several interviews conducted by Weismantel, she found that not only foreign travelers, but also locals in the Cuenca region, both male and female, were fearful of cholas. The author describes these experiences as uncanny in that the market women violate gender norms. "This public visibility of the female form, on display not for male delectation but for other purposes entirely, presents a symbolic inversion of the dominant sexual order that some find profoundly unsettling" (Weismantel, 2001: 53). In addition to this estrangement of gender, Weismantel argues that there is also a sense for foreigners that cholas may cheat them. "This uneasiness can translate into a suspicion that one has been fleeced: accusations of financial chicanery abound, even when, as is often the case, prices are fixed" (Ibid., 34). The chola exists and dominates a public space in which her job affords her with a status above that of women who do domestic work, and as we have seen, their image and reputation imply increased agency. Similar to the caudillo, the chola maintains her identity through the consistency of her image.

At the same time, despite their agency and economic power, it is also important to recognize the idea that they have also been treated as a commodity. Weismantel states that cholas were originally national symbols yet today they are considered valuable resources for the economy.

As tourism expands in otherwise contracting economies, such antiquated images (as the chola) become the only attractions capable of luring enough scare foreign currency to shore up the faltering prosperity of the middle class. [...] Cuenca wants tourists, and it believes that cholas will bring them (Weismantel, 2001: 27).

In this way, as the chola continues to cause newly arrived tourists and local elites discomfort, the Ecuadorian economy benefits as it needs her to be "scandalous" and "different", even if this means maintaining her economically challenged. Even within this system of trade in which she maneuvers money, goods, and minds, she must maintain a certain predictability in her dress, speech, and attitude. While she defies categories, her defiance has become a category for outsiders. She too, then, lives at a distance that is safely mysterious. In this way the chola identity is a paradigm within the discourses of dominated/dominator.

As we have seen, the collective groups and individual figures studied by these four authors allow us to critically approach notions of violence and agency. The carte-de-visite and the enslavement of Putumayo Indians are examples of extreme isolation and commodification. Taussig's account of the Putumayo presents the most extreme physical violence, yet symbolic violence abounds in the type carte. In contrast, the gaucho-caudillo collaboration as well as the 
cholas are examples of political and economic possibility within the paradigms of European dominance. They defy the categories that have been imposed on them, both historical and economic, by maneuvering within and around them through dynamic forms of exchange. While it is clear that paradigms of dominance play an important role in the types of exchange that exist between local elites, indigenous groups, and foreign capitalists in the Andean region as studied in these four cases, we have also seen that imaginaries fluctuate and change and therefore relationships of exchange maintain their complexity and need to be deciphered and contextualized.

\section{Acknowledgements}

This article received support from the Center for Intercultural and Indigenous Studies, at Pontificia Universidad Católica de Chile (FONDAP, 15110006).

\section{References}

Appadurai, A. (ed.) (1986). The social life of things: Commodities in cultural perspective. Cambridge: Cambridge of University Press.

De la Fuente, A. (2000). Children of Facundo: Caudillo and gaucho insurgency during the Argentine State formation process (La Rioja, 1853-1870). Durham: Duke University Press.

Nation Master (2005). 4 June 2005 - 19 June 2005. $<$ http://www.nationmaster.com/encyclopedia/Commodity-fetishism>

Poole, D. (1997). Vision, race and modernity: A visual economy of the Andean image world. Princeton: Princeton University Press.

Roldan, M. (2002). Blood and Fire: La Violencia in Antioquia, Colombia, 1946-1953. Durham: Duke University Press.

Taussig, M. (1987). Shamanism, colonialism and the wild man: A study in terror and healing. Chicago: University of Chicago Press.

Weismantel, M. (2001). Cholas and Pishtacos: Stories of race and sex in the Andes. Chicago: University of Chicago Press. 